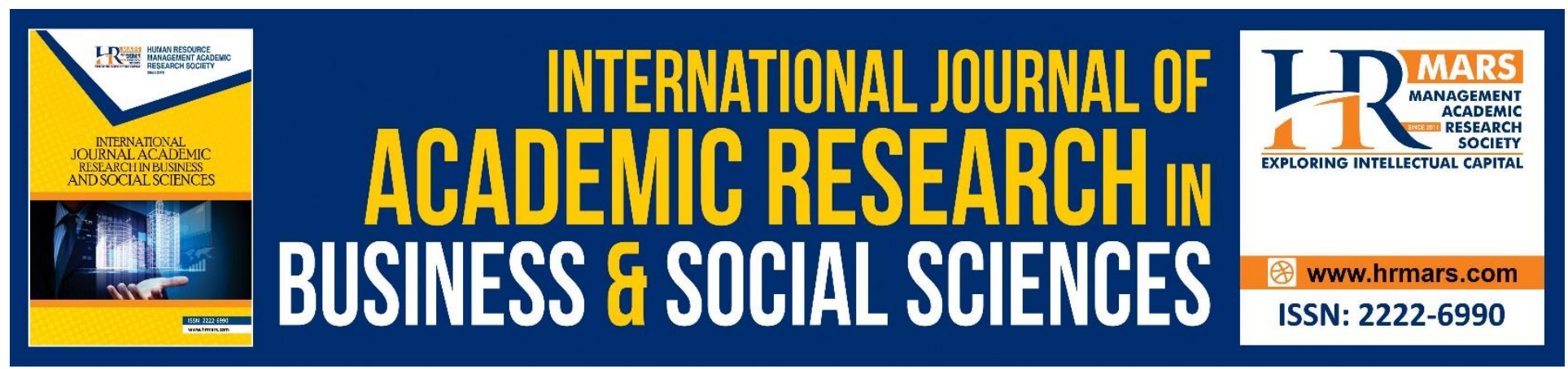

\title{
The Impact of Crude Oil, Natural Gas and Liquefied Natural Gas (LNG) Prices on Malaysia GDP: Empirical Evidence using ARDL bound Testing Approach
}

Nur Surayya Mohd Saudi, Wong Hock Tsen, Mohd Haziq Murshidi, Abdul Latif Harun, Amnah Saayah

To Link this Article: http://dx.doi.org/10.6007/IJARBSS/v9-i6/6060

DOI: 10.6007/IJARBSS/v9-i6/6060

Received: 13 April 2019, Revised: 11 May 2019, Accepted: 12 June 2019

Published Online: 30 June 2019

In-Text Citation: (Saudi, Tsen, Murshidi, Murshidi, \& Saayah, 2019)

To Cite this Article: Saudi, N. S. M., Tsen, W. H., Murshidi, M. H., Murshidi, M. H., \& Saayah, A. (2019). The Impact of Crude Oil, Natural Gas and Liquefied Natural Gas (LNG) Prices on Malaysia GDP: Empirical Evidence using ARDL bound Testing Approach. International Journal of Academic Research in Business and Social Sciences, 9(6), 988-1001.

Copyright: (C) 2019 The Author(s)

Published by Human Resource Management Academic Research Society (www.hrmars.com)

This article is published under the Creative Commons Attribution (CC BY 4.0) license. Anyone may reproduce, distribute, translate and create derivative works of this article (for both commercial and non-commercial purposes), subject to full attribution to the original publication and authors. The full terms of this license may be seen at: http://creativecommons.org/licences/by/4.0/legalcode

Vol. 9, No. 6, 2019, Pg. 988-1001

Full Terms \& Conditions of access and use can be found at http://hrmars.com/index.php/pages/detail/publication-ethics 


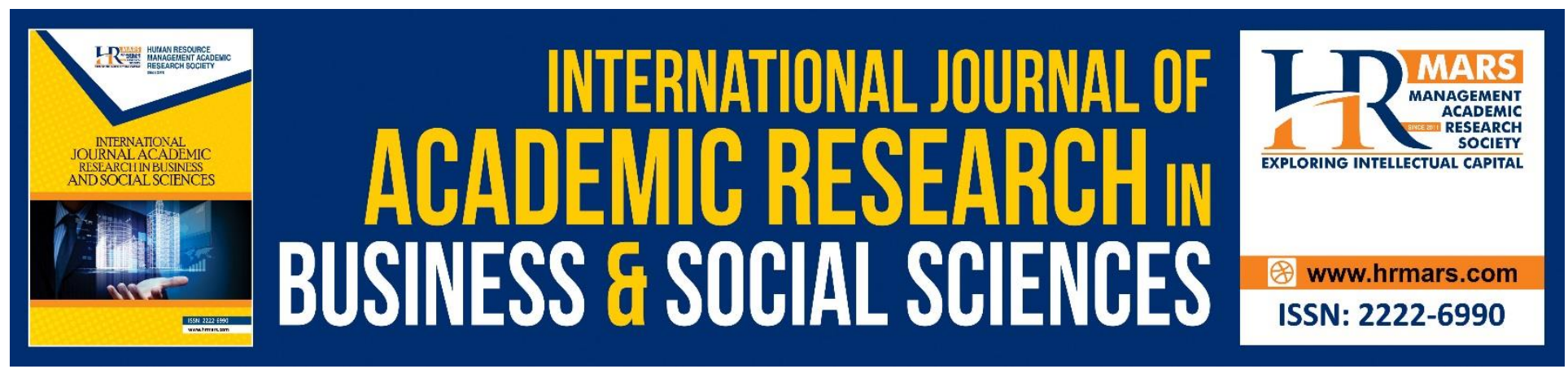

\title{
The Impact of Crude Oil, Natural Gas and Liquefied Natural Gas (LNG) Prices on Malaysia GDP: Empirical Evidence using ARDL bound Testing Approach
}

\author{
Nur Surayya Mohd Saudi ${ }^{1}$, Wong Hock Tsen², Mohd Haziq \\ Murshidi ${ }^{2}$, Abdul Latif Harun ${ }^{1}$, Amnah Saayah ${ }^{1}$ \\ ${ }^{1}$ National Defense University of Malaysia, ${ }^{2}$ Universiti Malaysia Sabah
}

\begin{abstract}
This paper attempted to investigate the impact of real crude oil, natural gas and liquefied natural gas (LNG) prices on Malaysia' Gross Domestic Product (GDP). Empirical analysis was based on the Autoregressive Distributed Lag (ARDL) estimates over a period of 30 years, from 1987 to 2017. The results revealed that the long- and short-run dynamics of GDP depended on the selected energy prices, given their dominant effects to Malaysia's economic growth. This paper will help policymakers to address the current focus on creating the right applications that can substitute for high dependency on crude oil. Meanwhile, higher consumption of natural gas and liquefied natural gas in industrial sectors and the use of cleaner energy sources other than non-renewable energies may have provided the motivation to create this paper.
\end{abstract}

Keywords: Crude Oil, Natural Gas, LNG, GDP, Macroeconomics

\section{Introduction}

The world had experienced the first oil price shock in 1973. During that time, the demand for oil had drastically increased following an oil crisis and global recessions. Several studies on the impact of oil price shocks revealed that oil prices had a significant effect on economic downturns. Oil prices were one of the major movers in the energy crisis of the early 70's and have piqued the world's interest ever since. The price of Brent crude oil saw an unprecedented spike, going from USD35 per barrel in the year 2000 to USD110 per barrel in 2011. And for 11 years, the world was facing an industrial revolution that led to a rapid oil demand from emerging countries like China and India. In 2014 however, the price of Brent crude dropped to USD98 a barrel, and fell as low as USD44 in 2016. Several different factors could have caused this phenomenon but the main ones were due to overproduction by the Organization of the Petroleum Exporting Countries (OPEC) and a global economic downturn. This paper aimed to assess the impact of oil, natural gas and LNG prices on Malaysia's GDP by adding consumer price index and real exchange rates as control variables. The rise in energy prices will cause other prices to rise too, which in turn, would drastically reduce household income and increase spending on energy, goods and services 
(Office, 2006). Following this implication, we are motivated to explore how oil, natural gas and LNG price fluctuations have affected Malaysia as a net exporter for oil and gas, and as mass energy consumers on the domestic front. Meanwhile, Taghizadeh-hesary and Yoshino (2015) has started exploration on the effect oil and gas prices have on emerging and developed countries like China, Japan and the US. In his argument, he suggested that developed countries would experience low impact of oil and gas fluctuations compared to emerging countries, like China. Further, Solarin and Shahbaz, 2015 said that having natural gas consumption, foreign direct investment, capital formation and trade openness might help influence the economic growth in Malaysia. Bear in mind that the issue of oil and gas prices has been important for some time already due to inflation. Malaysia ranks number three in dominating LNG exports, which at this current level, represents $10.2 \%$ of the world's LNG supply. The first and second biggest LNG exporters are Qatar and Australia, with contribution of $31.8 \%$ and $12 \%$ respectively.

\section{Figure 1 Malaysia Gross Export Products, 2016 in percentage}

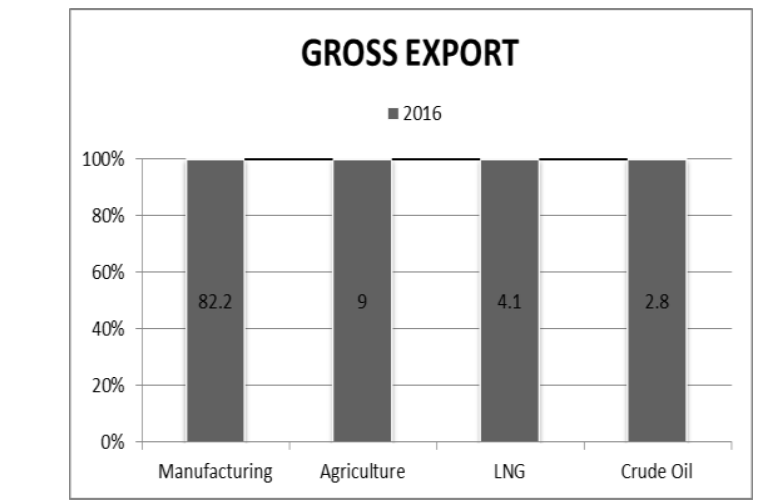

Source: Source: Bank Negara report 2016

Malaysia's GDP growth is accelerated by oil and gas export income, which represents the second highest contribution on the GDP, after electrics and electronics export. Figure 1 shows Malaysia's gross export in 2016, which reflected how crude oil and LNG played an important role in its economy. Although crude oil was reportedly the utmost energy consumed in Malaysia (Suruhanjaya tenaga report, 2016), natural gas was the third source of energy with the highest consumption in domestic markets. Despite the numbers, the world was moving towards cleaner and renewable energy-dominated systems, and this study had hoped to explore how natural gas and LNG could contribute to a high portion of back-up energy source. An earlier study by a Malaysian economist revealed that, Yusoff et al., (2000) in order to take advantage of the high oil prices during the 1980 's, Malaysia began transitioning its agricultural-based export to crude oil export, and the country has enjoyed a double-export income ever since.

The main objectives of the study are as follows:

1. To investigate the relationships of three energy sources namely crude oil, natural gas and liquefied natural gas (LNG) on Malaysia GDP.

2. To suggest policy recommendations on oil and gas price policy. 
INTERNATIONAL JOURNAL OF ACADEMIC RESEARCH IN BUSINESS AND SOCIAL SCIENCES Vol. 9, No. 6, June, 2019, E-ISSN: 2222-6990 @ 2019 HRMARS

\section{Literature Reviews}

Malaysia is a non-OPEC member with a profile of a net oil and gas exporter. In South East Asia, Malaysia is the second biggest oil exporter after Indonesia, yet only contributes $1 \%$ of the total crude oil production in the world (Energy Information Administration). However, as previously mentioned in (Yusma et al., 2013; Jaafar et al., 2008; and Izraf and Abu Bakar, 2011), oil price fluctuations and disruptions in its demand and supply will affect Malaysia's GDP performances.

Theoretically, the classical view suggested that oil and gas prices, which represent the input production, would influence the output production. In other words, the increase or decrease in price will affect the overall output (Abel and Bernake, 2001). Oil price relationships with macroeconomics have been extensively studied since the 1980's, by James, (1983) that concise the reason of US recession since World War II was mostly preceded during the spike up in oil prices. It was reported that nine out of ten reasons of the US recession came from oil price fluctuations. However, its impact could be controlled by monetary policies like interest and exchange rates as well as taxes (Hamilton, 1996). One study proved that a previously sharp rise in oil prices had caused threat to world economic growth (Difiglio, 2014), further emphasizing that the relationship between oil prices and GDP was highly significant with the combination of oil prices, exchange rates and precious metals was said to be co-integrated (Hooker, 1996).

In response to the oil and gas price boom recently, Hunt et al., (2015) study on the impact of oil and natural gas prices on the economy was conducted. The study's empirical results suggested that, for the next few decades, oil and natural gas prices would still give a rough impact to the economy, as both energies' rankings in highest global consumption levels remained unchanged. Based on the impact study of crude oil and natural gas price movement on GDP and consumer price index in the US, Japan and the Republic of China that has been conducted by Taghizadehhesary and Yoshino (2015) the findings suggested that developed countries like Japan and the US experience a milder effect of oil price fluctuations, as compared to the Republic of China. The paper also concluded that economies with a high fuel substitution (higher use of gas, nuclear electric, power gas and renewable energy) responded milder to crude oil fluctuations.

In ASEAN countries, fewer studies were carried out on the impact of oil and natural gas prices and its relationship with the economy. Perhaps among the ASEAN countries, only Indonesia, Malaysia, Thailand and Brunei have a profile of net oil exporters, with only a small contribution towards the oil production portion in the world market. In 2008, Indonesia reactivated its OPEC membership due to an increase in domestic oil consumption, which later led to an increase in its import value. The empirical results by Mulyadi et al.,(2012) said when Indonesia became a net oil importer, the country responded to oil price shocks with a lower GDP growth.

Despite short-term oil-price volatility, Malaysia's exporting of high quality crude oil while importing a lower quality crude oil for domestic use will continue to help underpin the country's GDP growth momentum. In fact, there is great demand for the high quality crude oil, known as the Kikeh crude oil, which is expensive in the world market. As such, the empirical results can justify the direct and indirect impact of energy prices to Malaysia as a net oil and gas exporter, and as an oil importer. 
The studies on the impact of crude oil prices on Malaysia's economy had generated many perspectives. Some researchers had solely focused on the impact of oil prices, while others explored the impact of oil consumptions on the macroeconomics. A study on the relationship between energy consumption, foreign direct investment, trade openness and economic growth confirmed that Malaysia's oil consumption had indeed affected its GDP Solarin and Shahbaz (2015).

According to a study published by Shaari et al., (2012) oil price fluctuations have a long-and short- run effect on Malaysia's consumer price index, while affecting the Malaysian exchange rate in the end. Having said that, several literatures suggested that a country's oil dependency might not help build the long-term goal of having sustainable energy policies, as such dependency will trap an economy by either a resource curse or a market distortion. Further studies by Bashiri Behmiri and Pires Manso (2012) also suggested that oil-dependent Organization for Economic Co-operation and Development (OECD) countries follow Japan and Korea who applied mixed energy policies to avoid high volumes of oil imports that are usually the cause of economic oil price shocks.

In this study, we assessed the impact of oil, natural gas and LNG prices on Malaysia's GDP growth by adding a consumer price index and real exchange rates as control variables. We looked at these factors as Malaysia is known as a net oil and gas exporter, and through this study, we hoped to answer the question whether Malaysia's economy is still responsive to oil prices, or if new oil-substitute energies like natural gas and LNG have sheltered the market from shock. Figure 2 is the crude oil natural gas reserved as reported by Suruhanjaya tenaga report (2016). Natural Gas reserved in trillion Cubic feet. As 2014, Malaysia still have a high natural gas reserved that made the purpose to explore the impact of natural gas and LNG prices to Malaysia economy more significant.

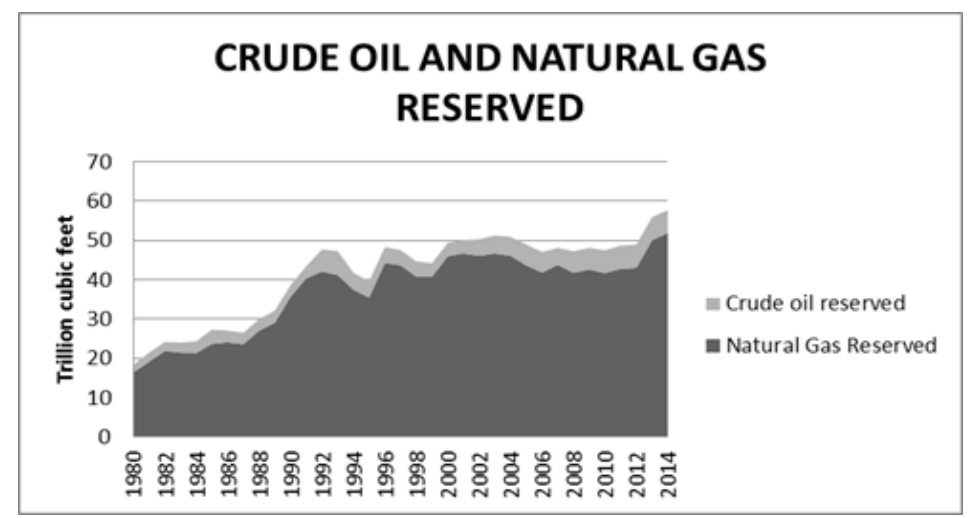

Figure 2 Crude oil and Natural gas reserved from 1980

Source: Suruhanjaya Tenaga report (2016) 


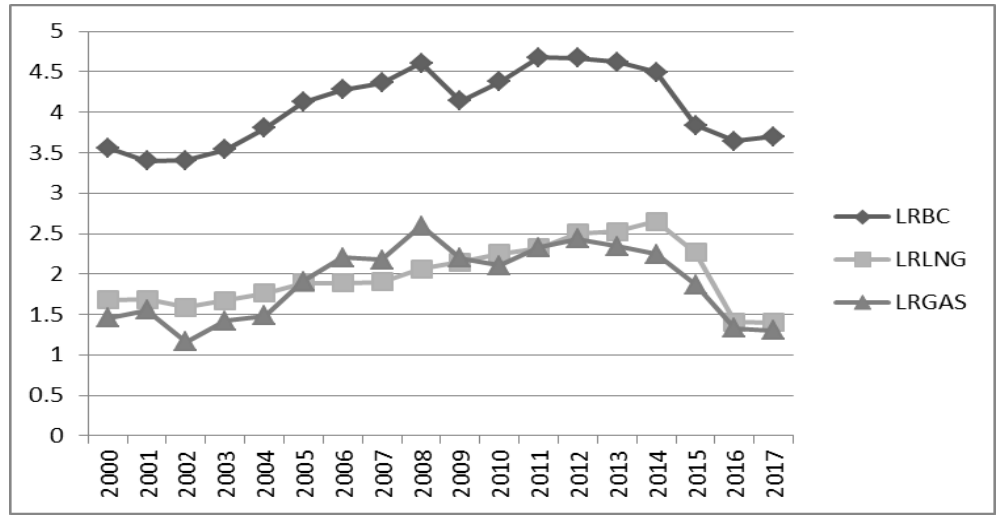

Figure 3 Brent crude oil, natural gas and LNG prices ${ }^{1}$ per USD from 2000 to 2017

Source: Federal reserved economic development

\section{Methodology}

In this study, we adopted ARDL bound approach that has been introduced by Pesaran and Shin (2001). We have selected this methodology as this econometrics analysis has a several advantages. First, the problem of endogenous is not considered in this approach, and all variables are considered as endogenous ones. Secondly, this model can be used in the case that it is based on a combination of static non-static and I (0) variables with different accumulation rates. Thirdly, The ARDL model is also appropriate for descriptive statistics and correlation matrix analyzing small sample size data and estimating the long- and short-run relationship together.

\section{Data}

Annual time series data was employed covering the period 1987 to 2017. The author only managed to collect a 30 years' time series data due to availability of data. In addition, Malaysia started consume and export natural gas and LNG's in the middle of from 1980's. Hence, the selection of years is justifiable. The empirical analysis included real Gross Domestic Product (RGDP), Consumer Price Index (CPI) and Real Exchange Rate (RER) that was extracted from World Development Indicators (WDI) while energy prices of Real Brent crude oil (RBC), Real Natural Gas price (RGAS) and Real Liquefied Natural Gas price (RLNG) were extracted from Federal reserved economic development Federal Reserved Economic Data (FRED) and Energy Information Administration (EIA). To ensure the stability of the data, we have converted to natural logarithm.

\section{Model specifications}

Following Mulyadi et al., (2012) and Taghizadeh and Yoshino (2015) we have constructs a multivariate model to explore the relationship of three energy prices with real GDP and 3 models was developed. 
LRGDP $=f($ LRBC, LCPI, LRER,

LRGDP $=f($ LRGAS, LCPI, LRER $)$

LRGDP $=f($ LRLNG, LCPI, LRER $)$

Consumer price index and exchange rate has been added as control variable. Theoretically aggregate supply will shift to the left as the input of production increases (energy price), Mulyadi et al., (2012). The dependent variable for this model is Real Gross Domestic Product (LRGDP) and the independent variable are three energy types prices namely Brent Crude, (LRBC), Natural gas (LRGAS) and Liquefied Natural (LRLNG). All the energy are in real value and converted to log before we running the data analysis by EVIEWS 9. Model specifications lead to ARDL approach to estimates the following unrestricted error correction model (UECM) by Ordinary Least Squares Method (OLS):

$\underline{\text { Model } 1}$

$$
\Delta \mathrm{LRGDP}_{\mathrm{t}}=\beta_{0}+\mathrm{rECT}_{\mathrm{t}-1}+\sum_{i=1}^{p} \alpha_{\mathrm{i}} \mathrm{LRGDP}_{\mathrm{t}-1}+\sum_{i=1}^{p} \delta \mathrm{LRBC}_{\mathrm{t}-1}+{ }_{\mathrm{t}-1} \sum_{i=1}^{p} \zeta_{\mathrm{i}} \mathrm{LCPI}_{\mathrm{t}-1}
$$

$+\sum_{i=1}^{p} \rho_{\mathrm{i}} \operatorname{LRER}_{\mathrm{t}-1}+\mathrm{v}_{\mathrm{I}}$

$\underline{\text { Model } 2}$

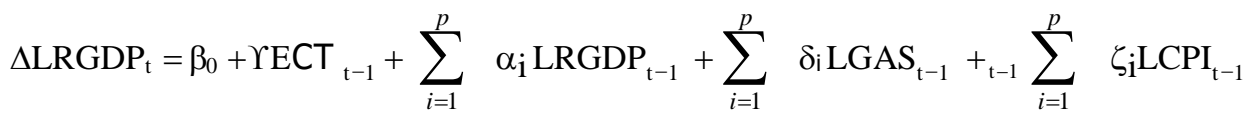

$+\sum_{i=1}^{p} \rho_{\mathrm{i}} \operatorname{LRER}_{\mathrm{t}-1}+\mathrm{v}_{\mathrm{I}}$

$\underline{\text { Model } 3}$

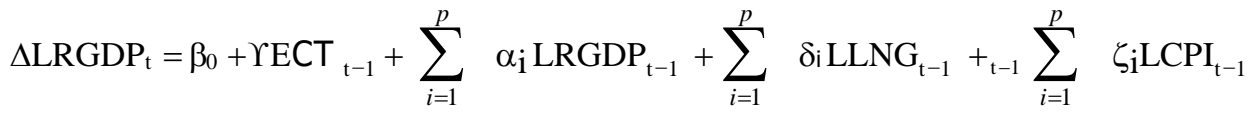

$+\sum_{i=1}^{p} \rho_{\mathrm{i}} \operatorname{LRER}_{\mathrm{t}-1}+\mathrm{v}_{\mathrm{I}}$

where $\Delta$ is the first difference operator and $u_{t}$ is a white-noise disturbance term. Residuals for the UECM should be serially uncorrelated, and the model should be stable. The existence of cointegration relationship between variables from_Eq. 4 to Eq. 6 is examined by testing the significance of the lagged levels of variables using the computed F-statistic. Pesaran et al propose testing: 
$\mathrm{H}_{0}: \theta_{0}=\theta_{1}=\theta_{2}=\theta_{3}=0$ (there is no long-run relationship).

$H_{1}: \theta_{0} \neq \theta_{1} \neq \theta_{2} \neq \theta_{3} \neq 0$ (there is a long-run relationship).

Following Pesaran et al, (2001). The F-statistic used for this test has a nonstandard asymptotic distribution and generated two sets of critical values bounds (the lower critical value and the upper critical value). The lower critical value corresponding to the case where all variables are $\mathrm{I}(0)$ and upper critical value corresponding to the case where all variables are I(1). If the computed F-statistic exceeds the upper critical bound, then the null hypothesis of the no cointegration is rejected and we can conclude that there is evidence of a long-run relationship. If it falls below the lower critical value, we do not reject the null hypothesis of no cointegration. Finally, if the Fstatistic is between the lower and upper critical bounds, the result is not conclusive.

\section{Empirical results}

\section{i) Unit root test ADF and Phillps -Perron}

Unit root test, ADF and PP confirms that none of the series is integrated of I(2). Table 1 displayed a mixed evidence of stationarity for the suggested variables at I(0) and I(1). Hence the results of unit root test fulfil the requirement to used ARDL estimation. Therefore, we may apply ARDL bounds testing procedures for establishing the long-run relationships.

\section{Table 1}

\begin{tabular}{ccclcc}
\hline & ADF & \multicolumn{2}{c}{ PP } & \\
\hline Variables & & Intercept & $\begin{array}{c}\text { Trend \& } \\
\text { Intercept }\end{array}$ & Intercept & $\begin{array}{c}\text { Trend \& } \\
\text { intercept }\end{array}$ \\
\hline LRGDP & $\mathrm{I}(0)$ & -1.723 & -2.523 & -1.753 & -2.513 \\
& $\mathrm{I}(1)$ & $-5.748^{* * *}$ & $-5.734^{* * *}$ & $-5.740^{* * *}$ & $-5.727^{* * *}$ \\
\hline LCPI & $\mathrm{I}(0)$ & -1.755 & -1.604 & -1.714 & -1.637 \\
& $\mathrm{I}(1)$ & $-4.462^{* * *}$ & $-4.804^{* * *}$ & $-4.561^{* * *}$ & $-4.85^{* * *}$ \\
\hline LRRER & $\mathrm{I}(0)$ & -1.866 & -0.0261 & -1.817 & -2.691 \\
& $\mathrm{I}(1)$ & $-4.919 * * *$ & $-0.4795^{* * *}$ & $-7.964 * * *$ & $-7.532^{* * *}$ \\
\hline LRBC & $\mathrm{I}(0)$ & -1.329 & -1.538 & -1.419 & -1.7253 \\
& $\mathrm{I}(1)$ & $-4.729 * * *$ & $-4.703^{* * *}$ & $-4.744 * * *$ & $-4.71 * * *$ \\
\hline LRGAS & $\mathrm{I}(0)$ & -1.532 & -1.457 & -1.590 & -1.610 \\
& $\mathrm{I}(1)$ & $-5.169 * * *$ & $-5.200^{* * *}$ & $-5.165 * * *$ & $-5.20^{* * *}$ \\
\hline LRLNG & $\mathrm{I}(0)$ & -2.275 & -2.418 & -1.296 & -0.928 \\
& $\mathrm{I}(1)$ & $-4.079 * *$ & $-3.964 * *$ & -3.584 & $-3.677^{* *}$ \\
\hline
\end{tabular}

Note: $(*),(* *),(* * *)$ indicate significant at $10 \%, 5 \%$ and $1 \%$ significance level respectively. 
INTERNATIONAL JOURNAL OF ACADEMIC RESEARCH IN BUSINESS AND SOCIAL SCIENCES

Vol. 9, No. 6, June, 2019, E-ISSN: 2222-6990 C 2019 HRMARS

\section{ii.ARDL Tests for Co-integration}

The results of computed F-statistics and the critical values suggested by Pesaran et al. (2001) at different levels of significance are given in Table 2 . The F-statistics is well beyond the critical value at $5 \%$ level of significance. Therefore, this is an evidence of strong long run relationship among the variables.

Table 2

\begin{tabular}{ccc}
\hline Model & AIC (Lag order) & F Statistic \\
\hline Brent & $(1,0,1,1)$ & $4.172^{* *}$ \\
LNG & $(1,0,1,1)$ & $3.820^{* *}$ \\
Gas & $(1,0,1,1)$ & $4.357^{* *}$ \\
\hline Critical Values for & Lower Bound, I (0) & Upper Bound, I(1) \\
F-statistics\# & & 4.68 \\
\hline $1 \%$ & 3.41 & 3.79 \\
$5 \%$ & 2.62 & 3.35 \\
\hline
\end{tabular}

Note: \# The critical values are obtained automatically under Eviews 9, $k$ is several variables (IV), critical values for the bounds test: case III: unrestricted intercept and no trend. ${ }^{* *}$, and ${ }^{* * *}$ represent $10 \%, 5 \%$ and $1 \%$ level of significance, respectively.

\section{iii. ARDL long -run elasticities}

The results of long run estimates are presented in Table 4. The coefficient value of -0.131 for model 1 indicated that Brent crude oil price have a negative relationship with economic growth (real GDP). An 1\% increase in Brent Crude oil price will reduce 13\% of GDP.This is also presented on model 2 that explain the coefficient value of -0.164 that represent an increase of $1 \%$ natural gas price will reduce $16 \%$ of GDP. While $1 \%$ increase in LNG will reduce $17 \%$ of GDP. The results for model 1, model 2 indicates the results is strong with $5 \%$ significant level. However, the results of LNG are significant but weak with at $10 \%$ significant level.

\section{Table 3}

\begin{tabular}{cc}
\hline IV & Coefficient \\
\hline Brent & $-\mathbf{0 . 1 3 1 ^ { * * }}$ \\
\hline CPI & $1.187^{* * *}$ \\
\hline RER & $1.160^{* *}$ \\
\hline & $(1,0,1,1)$ \\
\hline LNG & $-0.165^{*}$ \\
\hline CPI & $1.237^{* * *}$ \\
\hline RER & $1.612^{* *}$ \\
\hline GAS & $(1,0,1,1)$ \\
\hline CPI & $-\mathbf{0 . 1 6 4 ^ { * * }}$ \\
\hline EX & $1.270^{* * *}$ \\
\hline
\end{tabular}

Note: $\left({ }^{*}\right),\left({ }^{* *}\right),(* * *)$ indicate significant at $10 \%, 5 \%$ and $1 \%$ significance level respectively. 


\section{iv) Short Run Elasticities and Error Correction Term}

Next are the results for short-run elasticities that coefficient presented in error correction term. The short-run analysis for Brent Crude, and natural gas prices on real GDP produce the same negative sign as compared to long-run analysis. However, the magnitude of the short run estimates is smaller compare to long-run estimates. This analysis indicates that the Brent Crude oil and natural gas in the model have a stronger impact in a long-run compare in a short-run. However, LNG price response negative on real GDP and the results is not significant. Hence we can conclude that there is no short-run relationship between LNG price and real GDP. Table 4 presented the short-run elasticities.

\begin{tabular}{cc}
\hline IV & Coefficient \\
\hline Brent & $-0.035^{* *}$ \\
\hline CPI & $1.187^{* * *}$ \\
\hline RER & $1.160^{* *}$ \\
\hline ECT $_{(-1)}$ & $-0.267^{*}$ \\
\hline LNG & -0.037 \\
\hline CPI & $-1.2698^{* *}$ \\
\hline RER & $0.590^{* * *}$ \\
\hline ECT(-1) & $-0.224^{*}$ \\
\hline GAS & $-0.039^{* *}$ \\
\hline CPI & -0.917 \\
\hline Ex & $1.6149^{* *}$ \\
\hline ECT(-1) & $-0.2348^{* *}$
\end{tabular}

\section{Table 4}

Note: $\left({ }^{*}\right),\left({ }^{* *}\right),\left({ }^{* * *}\right)$ indicate significant at $10 \%, 5 \%$ and $1 \%$ significance level respectively.

\section{v) Diagnostic test}

After we obtained results for the model, the next steps are to ensure the model developed are free from econometric problem. Our model passes through the diagnostic tests. The results indicated the $p$-values of the $\chi 2$ state that there is no evidence of serial correlation and heteroscedasticity. Furthermore, the p-value of functional form is an evidence of well specification of the model and an indication of the acceptance of the null hypothesis of normality assumption of the residuals. Refer Table 5. Furthermore, the plots of CUSUM and CUSUMSQ statistics are well within the critical bounds, implying that all coefficients in the error-correction model are stable. Refer figure 1. 
Figure 1 Diagnostic Tests for Model
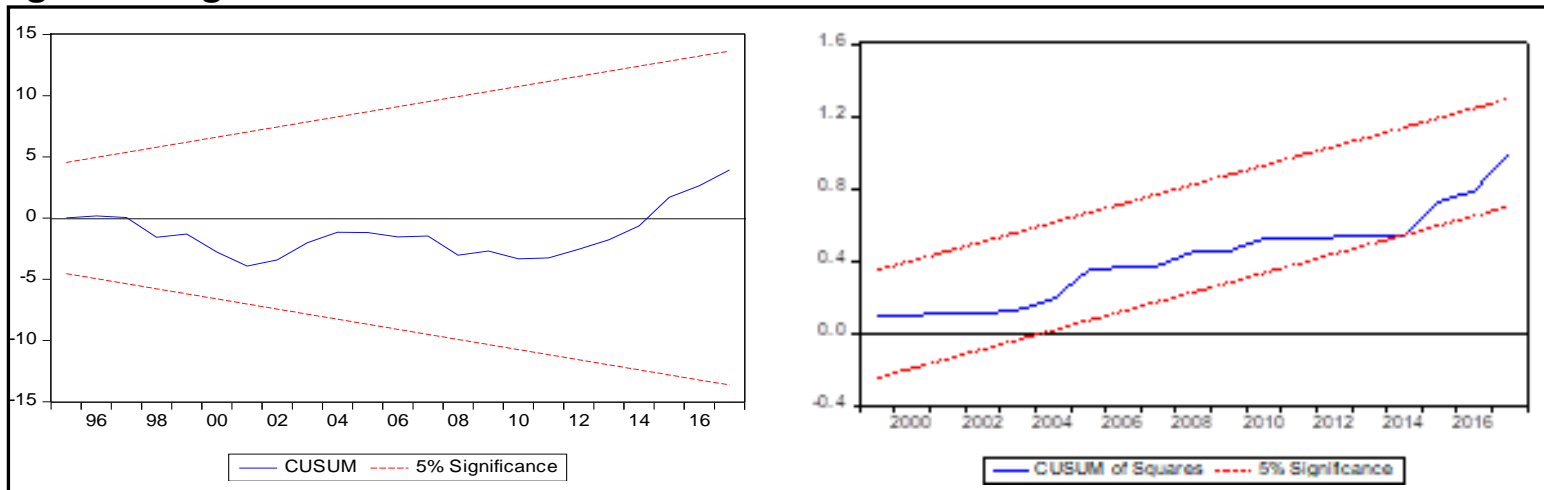

\begin{tabular}{lccc}
\hline \multirow{3}{*}{ Model } & A. Serial correlation & B. Normality & C. Heteroscedasticity \\
& $\chi^{2}(1)$ & $\chi^{2}(2)$ & $\chi^{2}(1)$ \\
{$[\mathrm{p}$-value $]$} & {$[\mathrm{p}$-value $]$} & {$[\mathrm{p}$-value $]$} \\
\hline LRBC & 1.63 & 1.99 & 1.76 \\
& {$[0.28]$} & {$[0.37]$} & {$[0.67]$} \\
LRGAS & 3.33 & 0.47 & 1.14 \\
& {$[0.14]$} & {$[0.78]$} & {$[0.47]$} \\
LRLNG & 0.89 & 0.57 & 1.06 \\
& {$[0.42]$} & {$[0.75]$} & {$[0.42]$} \\
\hline
\end{tabular}

\section{Table 5}

Note: The probability value of the battery of Diagnostic tests are presented in squared brackets.

\section{Discussion}

This study embarked on how oil, natural gas and LNG prices, as input of production, influenced the output (GDP). Some empirical findings from previous literatures confirmed that the impact of oil prices to a net oil exporter was positive due to the revenue received from the export. While net importer countries were having difficulties as their governments have had to carry the burden of the high oil price, while some literature confirmed that relationship is negative. Malaysia remained unique because it was exporting and importing crude oil and natural gas, both at the same time. Oil price shocks had retarded the output but the magnitude of shocks would have to depend on the level of oil intensity on the production side Gonzalez and Nabiyev (2009). This effect might be different in other countries though.

The empirical evidence on the impact of three-energy prices provided two potentially fruitful research findings. First, the present study explored the price impact of oil and natural gas, which were exported and highly consumed in domestic markets. Secondly, the impact of Brent crude oil price and LNG prices on an exporter country like Malaysia, who is the third largest LNG exporter in the world Research, (2016). 
INTERNATIONAL JOURNAL OF ACADEMIC RESEARCH IN BUSINESS AND SOCIAL SCIENCES Vol. 9, No. 6, June, 2019, E-ISSN: 2222-6990 @ 2019 HRMARS

\section{Conclusion}

The empirical findings indicate that there is a negative long-run relationship for Brent crude, natural gas, and LNG prices to the GDP. However, the magnitude for the long-run is higher compared to a short-run. This is supported from previous literature that said oil prices and the GDP have a long-run relationship. Latife, (2016) said that the impact of oil price fluctuations to economic growth is heterogeneous. The level of export dependence will strongly determine whether the oil price fluctuations have an impact or not. For example, Saudi Arabia, of which oil and gas contributed $35 \%$ of their GDP, suffered a decrease of $14.3 \%$ of the GDP when the oil price reduced by $60 \%$, compared to Mexico where oil and gas exports were $3.5 \%$ of the GDP and suffered a 3.9\% reduction in the GDP. The amount of oil dependency defines the level of the oil price effect on oil exporter countries.

In the Malaysian perspective, though we are a net oil and gas exporter2, the other sector that highly contributes to the GDP is the manufacturing sector Department of Statistic Malaysia. This sector is a highly consume oil and gas. Though oil and gas plays a significant role in generating Malaysian income, the effect of the increase in oil prices will retard the whole economy. However, Taghizadeh-hesary and Yoshino (2015) also said that oil prices and the GDP could react in a negative manner when the Eurozone exporter countries face a reduction in the GDP when oil prices increase. This happens when the exchange rate was high; and the input of production increases. Because of that, the products become expensive and the people's buying power decreases and affects the whole economy's performance.

This paper supports the classic supply side effect that suggests an increase in the input of production; will reduce the overall potential output (Abel and Bernanke, 2001), Brow and Yucel (2002). A decline in oil prices is beneficial to oil exporters due to the quantity effect outweighing the price effect (Rafiq and Sgro, 2016). This is in line with the findings by Surayya et al., (2018) that concluded a negative long-run relationship between Brent crude price on the output for manufacturing and services sectors in Malaysia that represent the highest contributors for Malaysia's overall GDP. The impact of the LNG price on the Malaysian economy is still unclear as the empirical results show that there is no short-run relationship with the real GDP, and the longrun effect is negative but with a low significant value which is also found in Surayya, (2017) that studied the impact of economic sector's GDP on LNG price. Perhaps LNG consumption is still low in the domestic market, which translates to less dependency on this energy.

As domestic oil continues to dominate the industrial sector as the second highest energy consumption, followed by natural gas, the author encourages the utilization of oil substitutions in all industries for the reason being that, Malaysia is equipped with high natural gas reserve that could last for at least 30 years, EIA (2017). If this effort is undertaken for a longer time horizon, it is likely to help reduce a country's oil dependency and encourage the use of mixed energy in the industrial sector. Malaysia should consider the implementation of natural gas especially in the 
transportation and industrial sectors, which will grow in value or generate long-term income. Natural gas has become an increasingly attractive fuel to replace petroleum, as it is cheaper and cleaner which dispicted by previous study (Surayya et al., 2017). Policy-makers should be mindful that a persistent decline in environmental quality that came from fuel carbon exert a negative externality to the economy in affecting human health and thereby reducing productivity in the long-run. Finally, it is suggested that Malaysia focus on the export growth of LNG rather than just using the energy for domestic consumption to gain export income.

\section{Acknowledgement}

The authors wish to express gratitude to Associate Professor Wong Hock Tsen for a constructive comments and National Defense University of Malaysia for funding support.

\section{Corresponding Author}

Nur Surayya Bt Mohd Saudi, NSS

University: National Defense University of Malaysia (NDUM).

Email: nursurayya@upnm.edu.my

\section{References}

Abel, A. B. and Bernanke, B. S. 2001. Macroeconomics. 4th edition

Behmiri, B. N., \& Pires Manso, J. R. (2012). Crude oil conservation policy hypothesis in OECD (organisation for economic cooperation and development) countries: A multivariate panel Granger causality test. Energy, 43(1), 253260.https://doi.org/10.1016/j.energy.2012.04.032

Brown, S. P. A. (2017). Natural gas vs. oil in U.S. transportation: Will prices confer an advantage to natural gas? Energy Policy, 110(February), 210221.https://doi.org/10.1016/j.enpol.2017.08.018

Brown, S. and Yucel, M. (2002) Energy prices and aggregate economy avtivities;An intepretative survey.The quarter; y reviews of economics and finance 42 (2),193-208.

Department of Statistic Malaysia (DOSM).https://www.dosm.gov.my/v1/

Difiglio, C. (2014). Oil, economic growth and strategic petroleum stocks. Energy Strategy Reviews, 5, 48-58. https://doi.org/10.1016/j.esr.2014.10.004

Energy Information Administration (EIA)(2017).https://www.eia.gov/petroleum/data.php Federal Reserved Economic Data (FRED)https://fred.stlouisfed.org/

Jomo, K. S., 1990, Growth and Structural Change in the Malaysian Economy, Macmillan, London. Gonzalez, A., \& Nabiyev, S. (2009). Oil price fluctuations and its effect on GDP growth, (January). Hamilton, J. D. (1996). This is what happened to the oil price-macroeconomy relationship. This Is What Happened to the Oil Price-Macroeconomy Relationship, 38, 215-220.

Hooker, M. A. (1996). What happened to the oil price-macroeconomy relationship? Journal of Monetary Economics, 38(2), 195-213. https://doi.org/10.1016/S0304-3932 (96)01281-0

Hunt, B., Muir, D., \& Sommer, M. (2015). The Potential Macroeconomic Impact of the Unconventional Oil and Gas Boom in the United States.

IndexMundi websites https://www.indexmundi.com/malaysi a/economy_profile.html 
Mulyadi, I. A. M., \& Newman, V. B. S. P. (2012). Oil Price, GDP, Inflation and Exchange Rate: Evidence from Indonesia as a Net Oil Exporter Country and a Net Oil Importer Country. International Institute of Social Studies. (Master Thesis)

Aziz, I. A. M., \& Abu Bakar, A. (2011). Oil Price Shocks and Macroeconomic Activities in Malaysia, 6(2), 123-142.

Jaafar, A. H., Chamhuri, S. \& Al-Amin, A. Q. (2008). Impacts of External Price Shocks on Malaysian Macro Economy-An Applied General Equilibrium Analysis. Economic Analysis Working Paper (EAWP), 7(10), 1-24.

Jain, A., \& Ghosh, S. (2013). Dynamics of global oil prices, exchange rate and precious metal prices in India. Resources Policy, 38(1), 88-93. https://doi.org/10.1016/j.resourpol.2012.10.001

Ghalayini, L. (2016). The Interaction between Oil Price and Economic Growth The Interaction between Oil Price and Economic Growth, (January 2011).Saudi, N. S. M., Tsen, W. H., Murshidi, M. H., Murshidi, M. H., \& Saayah, A. (2019). The Impact of Crude Oil, Natural Gas and Liquefied Natural Gas (LNG) Prices on Malaysia GDP: Empirical Evidence using ARDL bound Testing Approach. International Journal of Academic Research in Business and Social Sciences, 9(6), 817-830. 